\title{
Gambaran Penerapan Prinsip Benar Pemberian Obat di Rumah Sakit PKU Muhammadiyah Yogyakarta Unit II
}

\author{
Fatma Siti Fatimah ${ }^{1}$ \\ ${ }^{1}$ Universitas Alma Ata Yogyakarta \\ Jalan Ringroad Barat Daya No 1 Tamantirto, Kasian Bantul Yogyakarta \\ Email: fatmasitifatimah@gmail.com
}

\begin{abstract}
Abstrak
Insiden keselamatan pasien sangat merugikan pasien serta dapat menimbulkan hilangnya nyawa. Di Indonesia kesalahan pemberian obat merupakan insiden terbanyak. Insiden dapat terjadi dikarenakan salah satunya human error dari petugas kesehatan. Penelitian ini bertujuan untuk mengetahui gambaran karakteristik responden dalam penerapan prinsip benar pemberian obat di Rumah Sakit PKU Muhammadiyah Yogyakarta Unit II. Jenis penelitian ini adalah diskriptif kuantitatif. Responden diambil dengan teknik purposive sampling, yaitu sebanyak 32 orang perawat yang memenuhi kriteria inklusi. Instrumen menggunakan lembar observasi. Karakteristik responden berdasarkan usia paling banyak usia 25-35 tahun 56,2\%, jenis kelamin yaitu perempuan $90,7 \%$, lama bekerja yaitu $<1$ tahun $68,8 \%$, pendidikan yaitu D3 $84,4 \%$. Persentase penerapan prinsip benar pemberian obat paling banyak adalah dalam kategori cukup yaitu sebesar 69,4\%. Karakteristik responden berdasarkan usia paling banyak 25-35 tahun, jenis kelamin yaitu perempuan, lama bekerja yaitu $<1$ tahun, pendidikan yaitu D3. Penerapan prinsip benar pemberian obat adalah dalam kategori cukup.
\end{abstract}

Kata Kunci: usia, pendidikan, lama bekerja, benar obat

\section{Overview of Giving Right Medicine Principle in PKU Muhammadiyah Yogyakarta Unit II Hospital}

\begin{abstract}
Patient safety incidence make adverse patient and cause loss of life. Drug administration errors in Indonesia is the highest incidence. Incidents can occur due to human error one of health workers. This study aims to describe the characteristics of the respondent in the application of the principles of correct drug administration in PKU Muhammadiyah Yogyakarta Unit II Hospital. This research type is descriptive quantitative. Respondents were taken by purposive sampling, were 32 nurses who fulfill the inclusion criteria. The instrument uses an observation sheet. Characteristics of respondents by age at most $<25$ years of $56.2 \%$, based on sex is $90.7 \%$ female, long work is $<1$ year $68,8 \%$, education D3 $84.4 \%$. The percentage of correct application of the principle of drug administration most is in enough category is $69.4 \%$. Characteristics of respondents by age at most $<25$ years, gender is female, long work is $<1$ year, namely education D3. Application of principles of correct drug administration is in fair category.
\end{abstract}

Keywords: age, education, work period, right medicine principle

Info Artikel:

Artikel dikirim pada 2 Juni 2016

Artikel diterima pada 23 Juni 2016

DOI : http://dx.doi.org/10.21927/jnki.2016.4(2).79-83 


\section{PENDAHULUAN}

DepKes dalam panduan keselamatan pasien di rumah sakit melaporkan insiden keselamatan pasien yang paling banyak terjadi di Indonesia adalah kesalahan pemberian obat (1). Menurut Cahyono, setiap perawat wajib menerapkan keselamatan pasien (patient safety) untuk mencegah timbulnya kerugian yang dialami oleh pasien (2). Insiden kesalahan obat harus zero error di Rumah Sakit karena dampak yang ditimbulkan akan menyebabkan pasien memperpanjang hari rawat inap, menambah biaya perawatan, serta yang terburuk bisa mehilangkan nyawa pasien (3).

Joint Commission International $(\mathrm{JCl}) \&$ Wolrd Health Organitation (WHO) melaporkan beberapa negara sebanyak $70 \%$ insiden kesalahan pengobatan dan sampai menimbulkan cacat permanen pada pasien (4). Di Indonesia kesalahan pemberian obat tidak jarang menjadi tuntutan hukum (1). Indonesia sangat serius dalam memperhatikan keselamatan pasien sehingga mengadopsi dari $\mathrm{JCl}$ dan $\mathrm{WHO}$ terkait sasaran keselamatan pasien yang dimasukkan dalam akreditasi setiap rumah sakit, ini akan membuat setiap Rumah Sakit akan meningkatkan keselamatan pasien demi terjaminnya keselamatan pasien di rumah sakit (1).

Data di Rumah Sakit X di Sleman dimana insiden keselamatan pasien (IKP) paling banyak adalah kesalahan pemberian obat dibandingkan dengan pasien jatuh, salah identifikasi pasien, salah lokasi operasi, infeksi nosokomial. Tahun 2012 ada 2 insiden kesalahan pemberian obat oleh perawat di ruang rawat inap, 1 insiden di laboratorium salah pemberian label. Data tahun 2013 bulan Januari sampai Juni juga didapatkan laporan terbanyak IKP yaitu 2 insiden kesalahan pemberian obat di ruang rawat inap, masing-masing 1 kasus insiden pasien jatuh, kejadian nyaris cidera (KNC) salah transfusi darah pada pasien dan salah aff infus. Hal ini menunjukkan masih terjadi insiden keselamatan pasien terutama kesalahan pemberian obat, dimana seharusnya kesalahan pemberian obat tidak boleh terjadi. IKP kesalahan pemberian obat dapat dicegah dengan cara setiap perawat melakukan prinsip benar dalam memberikan obat pada pasien (3).

Kesalahan pemberian obat dapat terjadi jika petugas kesehatan termasuk perawat tidak menerapkan prinsip benar dalam pemberian obat. Menurut Tambayong, Berman et al, Potter \& Perry pemberian obat meliputi prinsip 10 benar yaitu obat, dosis, pasien, rute, waktu, informasi, kadaluarsa, pengkajian, evaluasi dan dokumentasi $(3,5,6)$. Banyak faktor yang mempengaruhi perilaku seseorang dalam menerapkan prinsip benar ini untuk meningkatkan keselamatan pasien.

Faktor penyebab IKP menurut Cahyono adalah kegagalan komunikasi dan human error yang menyebabkan kejadian malpraktek, meningkatkan biaya operasional, biaya perawatan penyembuhan dan menghambat proses pemberian asuhan keperawatan (2). Hasil penelitian Anugraheni menyebutkan banyak faktor yang mempengaruhi penerapan pedoman patient safety salah satunya faktor individu yaitu usia, pendidikan, masa kerja (7). Di dukung oleh penelitian Fachri masa kerja dan ciri kepribadian sangat mempengaruhi seseorang untuk berubah (8). Sehingga faktor kepribadian dan karakteristik individu inilah yang kemungkinan berkontribusi dengan insiden keselamatan pasien dan tidak menutup kemungkinan juga mempengaruhi seseorang untuk menerapkan prinsip benar dalam pemberian obat.

Berdasarkan latar belakang yang telah diuraikan di atas tujuan umum dalam penelitian ini adalah untuk mengetahui gambaran dalam penerapan prinsip benar pemberian obat di Rumah Sakit PKU Muhammadiyah Yogyakarta Unit II.

\section{BAHAN DAN METODE}

Penelitian ini merupakan penelitian kuantitatif, Notoatmodjo menyebutkan penelitian ini menggunakan diskriptif kuantitatif (9). Sampel penelitian ini adalah perawat pelaksana di ruang rawat inap bangsal Zaitun dan Wardah Rumah Sakit PKU Muhammadiyah Yogyakarta Unit II serta memenuhi kriteria inklusi dan ekslusi yang berjumlah 32 perawat. Kriteria inklusi dan eksklusi penelitian ini adalah kriteria inklusi: perawat pelaksana di ruang rawat inap Rumah Sakit PKU Muhammadiyah Yogyakarta Unit II, pendidikan D3 Keperawatan dan Ners serta bersedia berpartisipasi dalam penelitian ini. Kriteria ekslusi yaitu perawat pelaksana yang sedang cuti, perawat yang mengikuti pendidikan lanjutan yang meninggalkan tugasnya dirumah sakit.

Variable independent: tingkat pendidikan, lama bekerja dan jenis kelamin Perawat pelaksana dan variable dependent: prinsip benar pemberian obat. Tingkat pendidikan adalah jenjang terakhir yang diperoleh seorang perawat dalam penelitian ini 
adalah pendidikan D3 dan Ners. Lama bekerja adalah waktu seorang perawat terhitung mulai perawat bekerja di rumah sakit. Jenis kelamin adalah ciri atau karakteristik indivudu yang dibedakan menjadi perempuan dan laki-laki. Prinsip benar pemberian obat adalah Kegiatan perawat dalam melaksanakan tugas memastikan pemberian obat pada pasien yang menerapkan prinsip 10 benar yaitu benar pasien, rute atau jalur, nama obat, dosis, waktu, pengkajian, informasi, kadaluarsa, efek samping dan dokumentasi, cara pengukuran dengan menggunakan lembar observasi yang berisi 24 pernyataan dengan jawaban ya dan tidak, skala data yang digunakan adalah ordinal.

Instrumen penelitian menggunakan kuesioner dan lembar observasi. Kuesioner meliputi: Nama (diisi inisial), jenis kelamin, usia, pendidikan dan lama bekerja perawat. Lembar observasi digunakan untuk mengukur pelaksanaan prinsip benar pemberian obat injeksi berdasarkan kriteria standar pelaksanaan pemberian obat yang dikembangkan dari prinsip 10 benar pemberian obat menurut Tambayong, Berman et al, Potter \& Perry tentang indikator kesalahan pemberian obat dan penelitian Yaniantara lain benar pasien, benar rute atau jalur, benar obat, benar dosis, benar waktu, benar pengkajian, benar informasi, benar Kadaluarsa, benar evaluasi dan benar dokumentasi yang terdiri dari 24 pernyataan antara lain; benar pasien: perawat menanyakan identitas pasien sebelum pemberian obat, memastikan pemberian obat dengan melihat gelang identifikasi dan menyimpan obat pasien di kotak penyimpanan obat dan diberi nama pasien, benar rute atau jalur: perawat memberikan obat sesuai dengan instruksi dokter dan memastikan rute obat pada label obat, benar obat: perawat memastikan nama obat pada label, memastikan nama obat sesuai dengan buku injeksi atau rekam medis pasien dan memberikan obat dengan menggunakan label obat, benar dosis: perawat menyiapkan dosis obat sesuai dengan rekam medis dan memberikan obat sesuai dengan dosis, benar waktu: perawat memberikan obat pada pasien tepat waktu sesuai order dokter dan memberikan obat sesuai jadwal atau paling tidak 30 menit sebelum dan 30 menit sesudah jadwal ditetapkan, benar pengkajian: perawat melakukan pengkajian terkait diagnosis klien, benar informasi: perawat memberikan informasi terkait nama obat, menjelaskan cara pemberian obat dan menjelaskan fungsi atau kerja obat, benar kadaluarsa: perawat memastikan tanggal kadaluarsa obat dan memberikan obat pada pasien yang belum kadaluarsa, benar efek samping atau evaluasi: perawat melakukan evaluasi pasien setelah selesai pemberian obat dan memantau reaksi pasien terhadap pemberian obat, benar dokumentasi: perawat mencatat pemberian obat dalam rekam medis sesudah obat diberikan, mencatat waktu pemberian obat, mencatat rute pemberian obat dan memberikan paraf atau nama terang setelah pemberian obat $(3,5,6,10)$.

Instrumen penelitian ini disusun dari Tambayong, Berman et al, Potter \& Perry, serta penelitian Yani sehingga peneliti tidak melakukan uji validitas dan reliabilitas. Peneliti tidak melakukan uji normalitas karena skala data penelitian ini adalah ordinal. Analisa data yang digunakan adalah univariat karena dianalisis untuk satu variabel (11). Analisis univariat untuk mengetahui karakteristik penelitian hanya satu variabel. Etika penelitian yang dilakukan peneliti antara lain: Ijin di Rumah Sakit PKU Muhammadiyah Yogyakarta Unit II, informed consent, confidentiality, anonimity dan justice.

\section{HASIL DAN BAHASAN}

\section{Karakteristik Responden}

Karakteristik responden penelitian ini dapat dilihat di Tabel 1 yang menunjukkan karakteristik perawat di bangsal rawat inap berdasarkan usia, jenis kelamin, lama bekerja dan pendidikan.

Tabel 1. Gambaran Distribusi Frekuensi Karakteristik Responden

\begin{tabular}{lcc}
\hline Karakteristik responden & $\mathbf{n}$ & $\%$ \\
\hline Usia & & \\
$\quad<25$ tahun & 14 & 43,8 \\
25-35 tahun & 18 & 56,2 \\
Jenis kelamin & & \\
$\quad$ Laki-laki & 3 & 9,3 \\
$\quad$ Perempuan & 29 & 90,7 \\
Lama bekerja & & \\
$\quad<1$ tahun & 22 & 68,8 \\
$\quad$ 1-5 tahun & 10 & 31,2 \\
Pendidikan & & \\
$\quad$ D3 & 27 & 84,4 \\
$\quad$ Sarjana S1 atau Ners & 5 & 15,6 \\
$\quad$ Total & 32 & 100 \\
\hline
\end{tabular}

Sumber: Data Primer Tahun 2014

Kemudian secara umum karakteristik berdasarkan penerapan prinsip benar pemberian obat dapat dilihat pada Tabel 2. 
Tabel 2. Prinsip pemberian obat

\begin{tabular}{ccc}
\hline Penerapan prinsip Benar & $\mathbf{n}$ & $\%$ \\
\hline Baik & 13 & 40,6 \\
Cukup & 19 & 59,4 \\
Total & 32 & 100 \\
\hline
\end{tabular}

Sumber: Data Primer Tahun 2014

Karakteristik responden dalam penelitian ini antara lain: jenis kelamin, usia, pendidikan dan lama bekerja, meskipun dalam penelitian ini tidak dilakukan uji korelasi terhadap prinsip pemberian obat dikarenakan jumlah sampel yang minimal, namun hasilnya dapat dijelaskan, hasil penelitian menunjukkan bahwa sebagian besar responden berusia 25-35 tahun yaitu sebanyak 18 responden $(56,2 \%)$, dengan jenis kelamin perempuan sebanyak 29 responden $(90,7 \%)$, rentang usia semua responden masih dalam kategori dewasa muda.

Karakteristik responden berdasarkan usia yang terbanyak adalah usia 26-35 tahun yaitu 18 responden $(43,8 \%)$, walaupun demikian usia responden penelitian masih belum berbeda jauh karena berada dalam rentang 22-35 tahun. Menurut Robbins usia rentang tersebut masih dalam kategori dewasa muda yaitu diantara usia 20-40 tahun (12). Robbins juga menambahkan semakin bertambah usia maka semakin bertambah pengalaman, etika kerja yang kuat dan komitmen terhadap mutu. Hal ini juga menunjukkan, semua responden masih mempunyai kesempatan yang sama dalam hal belajar untuk meningkatkan mutu rumah sakit termasuk berkomitmen terhadap keselamatan pasien.

Pada umumnya semua responden masih dalam rentang usia dewasa muda menurut Prof Sumiyati dalam Efendi dan Makhfudli (13). Sehingga dikaitkan dengan tingkat pendidikan yang lebih didominasi D3 serta lama pengalaman kerja perawat di rumah sakit didominasi oleh perawat baru maka bisa di simpulkan pada usia dewasa muda ini untuk berubah menjadi ke arah lebih baik yakni dalam hal menjalankan prinsip benar pemberian obat masih sangat mungkin dilakukan dan ketika prinsip dilakukan sesuai dengan standar yang berlaku maka akan menciptakan keselamatan pasien.

Usia merupakan sesuatu hal yang penting yang dapat mempengaruhi pengetahuan serta sejalan dengan pengetahuan maka akan mempengaruhi tingkah laku seseorang, semakin usia bertambah maka pengetahuan akan meningkat (14). Jenis kelamin mempengaruhi terkait dengan cara bersikap dengan orang lain khususnya dengan lawan jenis (12). Tidak menutup kemungkinan juga mempengaruhi baik sesama rekan kerja perawat ataupun dengan pasien, seseorang akan lebih bertindak hati hati dengan lawan jenis.

Karakteristik responden berdasarkan masa kerja didominasi karyawan baru yang bekerja kurang dari 1 tahun sebanyak 22 responden (68,8\%). Lama bekerja merupakan salah satu faktor individu yang berhubungan dengan perilaku dan prestasi individu. Dalam memandang sesuatu pekerjaan karyawan baru akan beroriantasi berbeda dengan karyawan yang sudah bekerja 10 tahun (15). Karyawan baru akan berorientasi pada terselesaikannya tugas dengan baik dan menganggap keberhasilannya adalah prestasi. Pendidikan merupakan faktor yang mempengaruhi perilaku seseorang. Dalam berperilaku sejalan dengan pendidikan atau pelatihan dan masa kerja seseorang akan mempengaruhi kemampuan perawat menyelesaikan pekerjaan sehari-hari.

Karakteristik responden berdasarkan jenis kelamin paling banyak adalah responden perempuan yaitu 29 responden $(90,7 \%)$, faktor jenis kelamin menurut Sopiah menyatakan pegawai wanita cenderung lebih rajin, teliti dan sabar dibandingkan laki-laki (16). Hal ini didukung oleh pendapat Ekstorm dalam Mustika, bahwa perawat perempuan cenderung lebih baik dan teliti dalam memberikan asuhan keperawatan dibandingkan laki laki (17). Terbukti dalam penelitian ini seluruh perawat sebanyak $90,7 \%$ menerapkan prinsip benar dalam kategori cukup dan tidak ada dalam kategori kurang. Karakteristik lama bekerja paling banyak adalah karyawan baru yang bekerja $<1$ tahun yaitu 22 responden $(68,8 \%)$, Faktor lamanya masa kerja menurut Sopiah semakin lama karyawan bekerja semakin meningkat juga loyalitas serta pengalaman karyawan tersebut (16).

Karakteristik berdasarkan pendidikan paling banyak adalah D3 keperawatan yaitu 27 responden $(84,4 \%)$. Pengetahuan berhubungan dengan proses penerimaan infomasi, dimana semakin tinggi tingkat pendidikan semakin tinggi pula tingkat penerimaan informasi dan mendorong untuk melakukan sesuai dengan penerimaan individu. Robbins menyebutkan semakin tinggi tingkat pendidikan seorang karyawan, semakin baik karyawan dalam melakukan pekerjaannya (12). Penelitian ini semua responden merupakan seorang perawat yang sudah menempuh pendidikan tinggi, sehingga harapannya semua perawat mampu menerima melakukan pekerjaannya 
dengan baik seperti menerapkan prinsip 10 benar dalam pemberian obat.

Penerapan prinsip benar pemberian obat oleh perawat dikelompokkan menjadi dua kategori yaitu cukup dan baik serta tidak ada perawat yang kurang dalam penerapan prinsip ini. Dari Tabel 2 dapat dilihat persentase perawat dalam penerapan prinsip benar dalam kategori baik yaitu sebanyak 13 perawat $(40,6 \%)$ dan paling banyak dalam kategori cukup yaitu sebanyak 19 perawat $(59,4 \%)$. Berdasarkan karakteristik responden dan hasil observasi pelaksanaan prinsip benar pemberian obat ini maka dapat diketahui bahwa rata rata responden mempunyai karakteristik yang hampir sama. Sehingga hal ini yang kemungkinan menyebabkan persentase penerapan prinsip benar tidak ada yang dalam kategori kurang. Untuk membuktikan ini maka diperlukan penelitian lanjutan terkait faktor yang berhubungan dengan penerapan prinsip benar pemberian obat tentunya dengan jumlah sampel yang lebih banyak yang bisa digeneralisirkan nanti hasilnya.

\section{SIMPULAN DAN SARAN}

Berdasarkan hasil dan bahasan dapat ditarik kesimpuan bahwa karakteristik responden berdasarkan usia paling banyak $25-35$ tahun $56,2 \%$, berdasarkan jenis kelamin yaitu perempuan $90,7 \%$, lama bekerja yaitu $<1$ tahun $68,8 \%$, pendidikan D3 yaitu $84,4 \%$ dan persentase penerapan prinsip benar pemberian obat paling banyak adalah dalam kategori cukup yaitu sebesar $69,4 \%$ dan dalam kategori baik sebanyak $40,6 \%$.

Diharapkan untuk perawat di Rumah Sakit PKU Muhammadiyah dan seluruh petugas kesehatan untuk meningkatkan penerapan prinsip benar pemberian obat kepada pasien sehingga menciptakan keselamatan pasien di rumah sakit. Peneliti selanjutnya disarankan untuk menilai korelasi dari karakteristik individu dengan penerapan prinsip benar pemberian obat kemudian menambah jumlah sampel penelitian.

\section{RUJUKAN}

1. Depkes RI. Panduan nasional keselamatan pasien rumah sakit (patient safety). 2nd ed. Jakarta: Depkes RI; 2008.
2. Cahyono. Membangun budaya keselamatan pasien dalam praktek kedokteran. Yogyakarta: Kanisius; 2008.

3. Potter PA, Perry AG. Fundamental of nursing fundamental keperawatan. 7th ed. Jakarta: Salemba Medika; 2009.

4. World Health Organization \& Joint Comission International. Communication during patient hand-overs [Internet]. [cited 2014 Jan 1]. Available from: http://www.who.int/patientsafety/solutions/ patientsafety/PS-Solution3.pdf

5. Tambayong J. Farmakologi Keperawatan. Ester M, editor. Jakarta: Widya Medika; 2005.

6. Berman A, Snyder S, Kozier B, Erb G. Buku ajar praktik keperawatan klinis. 5th ed. Ariani F, editor. Jakarta: EGC; 2009.

7. Anugraheni $C$. Hubungan faktor individu dan organisasi dengan kepatuhan perawat dalam menerapkan pedoman patient safety di RSAB Harapan Kita Jakarta. Depok; 2010.

8. Fachri MW. Hubungan ciri kepribadian usia, masa kerja, tingkat pendidikan, jenis kelamin dengan kesiapan untuk berubah. Jakarta; 2008.

9. Notoatmodjo S. Metodologi Pendidikan Kesehatan. Jakarta: Rineka Cipta; 2009.

10. Yani S. Evaluasi penerapan pemberian obat secara parenteral dalam menyelenggarakan patient safety di instalaasi rawat inap Rumah Sakit PKU Muhammadiyah Bantul. Yogyakarta; 2012.

11. Dahlan SM. Statistik untuk kedokteran dan kesehatan. 5th ed. Jakarta: Salemba Medika; 2011.

12. Robbins PS, Judge TA. Perilaku organisasi. 12th ed. Jakarta: Salemba Empat; 2008.

13. Efendi F, Mahkfhfudli. Keperawatan kesehatan komunitas teori dan praktek dalam keperawatan. Nursalam, editor. Jakarta: Medika Salemba; 2009.

14. Hurlock EB. Psikologi perkembangan: Suatu Pendekatan Sepanjang Kehidupan. 5th ed. Jakarta: Erlangga; 2015.

15. Laurens JM. Arsitektur dan perilaku manusia. Diana N, editor. Jakarta: Grasindo; 2005.

16. Sopiah. Perilaku organisasi. Yogyakarta: Penerbit Andi; 2009.

17. Mustika AS, Effendy C, Setiyarini S. Gambaran penerapan prinsip enam benar pada pemberian obat pada tindakan injeksi. JIK. 2008;3(3):151-8. 